\title{
Prevalensi Infeksi Saluran Kemih pada Penderita Diabetes Mellitus Tipe 2 di RSUD Sultan Syarif Mohammad Alkadrie Pontianak
}

\author{
Moch. Taufiq Widiatmoko ${ }^{1}$, Willy Brodus Uwan ${ }^{2}$, Mahyarudin ${ }^{3}$ \\ ${ }^{1}$ Program Studi Kedokteran, FK UNTAN \\ ${ }^{2}$ SMF Ilmu Penyakit Dalam, RS St.Antonius Pontianak \\ ${ }^{3}$ Departemen Mikrobiologi, Program Studi Kedokteran, FK UNTAN
}

\begin{abstract}
Abstrak
Latar Belakang. Diabetes mellitus (DM) adalah suatu penyakit metabolik dengan karakteristik hiperglikemia yang disebabkan kelainan sekresis insulin, kerja insulin atau kedua-duanya. ${ }^{1,2}$ Pada tahun 2030 diperkirakan terjadi kenaikan pasien DM hingga 21,3 juta, ${ }^{2}$ yang diikuti dengan peningkatan komplikasi kronik $\mathrm{DM},{ }^{3}$ dan komplikasi infeksi tersering adalah Infeksi saluran kemih (ISK). ${ }^{4}$ Sebanyak 69\% pasien ISK pada penderita DM adalah asimptomatik, ${ }^{5}$ dan resiko 16 kali pada pasien DM wanita berusia lebih dari 60 tahun. ${ }^{6}$ Pentingnya pencegahan dini dan kurangnya informasi di kota Pontianak mendasari dilakukan penelitian ini. Metode. Desain penelitian menggunakan metode deskriptif dengan pendekatan cross sectional. Pengambilan sampel dilakukan dengan metode consecutive. Pemeriksaan urin dilakukan menggunakan metode kultur pada media agar Mc Conkey; Hasil. Dari 89 total sampel tidak terdapat hasil positif infeksi saluran kemih berdasarkan pemeriksaan kultur urin. Gejala infeksi saluran kemih yang sering muncul pada penderita diabetes melitus adalah frekuensi. Dari pemeriksaan mikroskopik sebanyak 91,76\% ditemukan basil gram negatif. Kesimpulan. Prevalensi ISK pada DM tipe 2 di RSUD Sultan Syarif Mohamad Alkadrie Pontianak sebesar 0\% dan tidak ada pasien DM tipe 2 yang positif ISK.
\end{abstract}

Kata kunci : Prevalensi, Diabetes mellitus tipe 2, Infeksi Saluran Kemih, Kultur urin

Background. Diabetes mellitus (DM) is a metabolic disease with characteristics of hyperglycemia caused by secretive abnormalities of insulin, insulin work or both. ${ }^{1,2}$ In 2030 it is estimated that there will be an increase in DM patients up to 21.3 million. ${ }^{2}$ followed by an increase chronic complications of $D M,{ }^{3}$ and complications of the most common infections are urinary tract infections (UTI). ${ }^{4}$ As many as $69 \%$ of UTI patients in patients with DM are asymptomatic, ${ }^{5}$ and 16 times the risk of DM patients in women over 60 years of age. ${ }^{6}$ The importance of early prevention and lack of information in the city of Pontianak underlies this research. Method. The research design used descriptive method with cross sectional approach. Sampling process used consecutive method. The examination of urine used culture method in Mc Conkey's agar media; Result. A total of 89 samples there is no patients with positive urinary tract infections based on urine culture examination. Symptoms of UTI that often appear in people with DM are frequency. Base on microscopic test found 91,76\% sampel has Bacil gram negative. Conclusion: The prevalence of UTI in type 2 DM in Sultan Syarif Mohamad General Hospital Alkadrie Pontianak was 0\%.

Keywords : Prevalence, Diabetic Mellitus type 2, Urinary Tract Infection, Urine Culture. 


\section{PENDAHULUAN}

Diabetes mellitus (DM) adalah suatu kelompok penyakit metabolik dengan karakteristik hiperglikemia yang terjadi karena kelainan sekresis insulin, kerja insulin atau kedua-duanya.1,2 Penyakit DM sangat berpengaruh terhadap kualitas sumber daya manusia dan berdampak pada peningkatan biaya kesehatan yang cukup besar. Di Indonesia, jumlah penderita DM pada tahun 2030 diperkirakan berjumlah 21,3 juta. Di masa mendatang akan menjadi beban yang sangat berat untuk di tangani oleh dokter spesialis/subspesialis atau bahkan semua tenaga kesehatan yang ada. $^{2}$

Peningkatan kejadian DM tentu akan diikuti dengan peningkatan kemungkinan terjadinya komplikasi kronik DM.3 Secara umum komplikasi DM dibagi menjadi 2, yaitu komplikasi makrovaskular dan komplikasi mikrovaskular. Komplikasi makrovaskular terdiri dari Coronary artery disease, peripheral arterial disease, dan stroke. Komplikasi mikrovaskular terdiri dari diabetic nephropathy, neuropathy, dan retinopathy. $^{4}$

Pada observasi klinis juga didapat hubungan antara DM dan peningkatan kerentanan dan kuatnya infeksi. Infeksi saluran kemih adalah infeksi yang paling sering terjadi. Hal ini terjadi seiring meningkatnya frekuensi dan kuatnya pada populasi diabetes, dan berhubungan dengan komplikasi DM. ${ }^{5}$

Infeksi saluran kemih atau (ISK) adalah istilah umum yang menunjukkan adanya mikroorganisme di dalam urin. Infeksi saluran kemih merupakan salah satu penyakit infeksi yang sering ditemukan di praktik umum. Infeksi saluran kemih sering di tandai dengan demam, susah buang air kecil, dysuria terminal, polakisuria, nokturia, anyanganyangan, nyeri pinggang dan nyeri suprapubic. Pada pemeriksaan fisik di temukan flank pain, yaitu nyeri ketok pinggang belakang (costovertebral angle), ${ }^{6}$ namun infeksi saluran kemih juga dapat tanpa disertai manifestasi klinis 
(asimtomatis). ${ }^{2}$ Hal ini sejalan dengan penelitian yang dilakukan Ariwijaya yang mendapatkan 69\% ISK pada DM adalah asimptomatik. $^{7} \quad$ Untuk pendekatan diagnosis ISK dapat dilakukan hitung jumlah bakteri pada urin (bakteriuria). ${ }^{2}$ Bakteriuria bermakna jika pada biakan urin di dapat pertumbuhan mikroorganisme lebih dari $10^{5}$ colony forming units (cfu/ml). ${ }^{3,7}$

Pada penelitian yang dilakukan Saptningsih didapatkan bahwa, usia pasien DM wanita $>60$ tahun 16 kali beresiko mengalami ISK. $^{8}$ Hasil ini mengimplikasikan untuk tenaga kesehatan untuk lebih perhatian dan bersiaga untuk mencegah dan identifikasi dini ISK. ISK yang tidak terdiagnosis pada penyakit DM ataupun yang tidak tertangani dengan baik akan memperburuk prognosis dengan timbulnya komplikasi lain yang tentu akan mempersulit jalan kesembuhan bagi pasien. Juga minimnya informasi khususnya di kota Pontianak ini tentang prevalensi ISK pada penderita DM yang mendasari dilakukannya penelitian ini. Identifikasi dini ISK pada pasien DM menuntun kita kepada tatalaksana yang sesuai, untuk mendapatkan hasil yang diinginkan dan menghindari komplikasi lain sehingga tidak memperburuk prognosis.

\section{METODE}

Desain penelitian yang digunakan yaitu studi deskriptif dengan pendekatan cross sectional. Pengambilan sampel dengan teknik consecutive sampling Penelitian eksplorasi dengan cara menghitung jumlah bakteri pada urin penderita diabetes melitus (DM) tipe 2 yang di rawat di RSUD Sultan Syarif Mohamad Alkadrie Pontianak, Kalimantan Barat.

Jumlah sampel pada penelitian ini sebanyak 89 sampel dengan kriteria termasuk pasien diabetes melitus tipe 2 , bersedia menjadi subjek penelitan dan sedang tidak menggunakan obat antibiotic dalam waktu 2 minggu terahir. 
Sampel urin penderita DM diperoleh menggunakan prosedur urin porsi tengah. Kemudian urin disimpan di dalam tabung tertutup rapat dan disimpan di dalam tempat berisi es untuk mengurangi penguapan dan menjaga agar sampel tidak rusak atau berubah selama perjalanan. ${ }^{9}$ Sampel yang terkumpul dibawa ke Laboratorium Mikroskopis di Fakultas Kedokteran Universitas Tanjungpura kota Pontianak.

Pengujian sampel yang dilakukan pada penelitian menggunakan pemeriksaan tidak langsung yaitu kultur pada media tumbuh McConkey. Prosedur kultur menggunakan metode gores. Sebanyak $100 \mu 1$ sampel urin dimasukkan ke media agar, kemudian digores menggunakan ose steril. Kemudian lempeng tersebut diinkubasi dalam 24 jam pada suhu $35^{\circ} \mathrm{C}$. Perhitungan pertumbuhan bakteri pada keesokan harinya. $^{9}$

Perhitungan dilakukan terhadap jumlah koloni pada cawan petri antara 30300. Perhitungan dilakukan dengan mengalikan jumlah koloni yang ditemukan dengan 10. Jika jumlah yang didapat kurang dari 30 koloni akan menghasilkan penghitungan yang kurang teliti secara statistik, namun bila lebih dari 300 akan menghasilkan hal yang sama karena terjadi persaingan antara koloni. Apabila didapatkan jumlah bakteri lebih dari 105 $\mathrm{cfu} / \mathrm{ml}$ dapat didiagnosis ISK pada semua pasien termasuk pasien wanita tanpa gejala. ${ }^{10}$ Setelah didapat jumlah penderita ISK, dilajutkan dengan menghitung prevalensinya dengan rumus: $:^{11}$

$$
\text { Prevalensi }=\frac{\text { jumlah kasus }}{\text { jumlah populasi }} 100 \%
$$

yang bisa kita modifikasi dan sesuaikan menjadi:

$$
\text { Prevalensi }=\frac{\text { jumlah kasus ISK }}{\text { jumlah kasus DM }} 100 \%
$$

\section{HASIL}

Pengumpulan sampel dilakukan mulai dari tanggal 25 oktober 2018 hingga 3 februari 2019. Pengambilan sampel dalam penelitian ini menggunakan teknik consecutive sampling, pada pasien DM 
tipe 2 yang berkunjung ke RSUD Sultan Syarif Mohamad Alkadrie Pontianak.

Sebaran Usia Pasien Diabetes Melitus.

Jumlah pasien yang terdata dalam penelitian ini sebanyak 103 pasien diabetes melitus, 13 diantaranya sedang menggunakan antibiotik sehingga harus dieksklusikan, dan tersisa 89 pasien. Penelitian ini diikuti oleh seluruh pasien diabetes melitus tanpa batasan usia dan jenis kelamin. Usia termuda pasien diabetes melitus yang mengikuti penelitian ini berumur 18 tahun, dan pasien tertua 74 tahun, dengan rata-rata usia 58 tahun.

Karakteristik Pasien Diabetes Melitus.

Pasien terdiri dari 38 orang lakilaki $(42,70 \%)$ dan 51 orang perempuan $(57,30 \%)$. Sebanyak 45 orang pasien berumur kurang dari 60 tahun $(50,56 \%)$, dan 44 orang $(49,44 \%)$ pasien berumur lebih dari sama dengan 60 tahun. Pasien yang menderita diabetes melitus kurang dari sama dengan 10 tahun sebanyak 63 orang pasien $(70,79 \%)$, pasien yang menderita diabetes melitus selama 11 sampai 20 tahun sebanyak 20 orang pasien $(22,47 \%)$, pasien yang menderita diabetes melitus lebih dari 20 tahun sebanyak 6 orang pasien $(6,74 \%)$. Berdasarkan ada tidaknya gejala infeksi saluran kemih yang muncul, dari hasil wawancara didapatkan sebanyak 60 pasien $(67,42 \%)$ terdapat gejala infeksi saluran kemih yang timbul, sedangkan 29 orang pasien $(32,58 \%)$ tidak timbul gejala infeksi saluran kemih.

\section{Hasil Pemeriksaan Kultur Urin}

Jumlah sampel yang memenuhi kriteria inklusi dan eksklusi berjumlah 89 orang. Setelah dilakukan pemeriksaan urin, dari seluruh sampel tidak ditemukan hasil positif ISK.

\section{Sebaran Gejala Pada Pasien Diabetes Melitus}

Gejala yang banyak dirasakan adalah frekuensi $(41,57 \%)$, dan gejala yang paling sedikit dirasakan adalah disuria dan demam masing masing $6,74 \%$. Pada penelitian ini didapatkan gejala terbanyak yang dirasakan pasien diabetes melitus 
adalah frekuensi, dan yang paling sedikit adalah dysuria dan demam

Sebaran jenis Gram bakteri pada pasien diabetes melitus tipe 2 dan positif ISK

Dari pemeriksaan mikroskopis ditemukan 78 sampel $(91,76 \%)$ dengan basil Gram negatif, dan sebanyak 7 sampel $(8,24 \%)$ dengan Coccus Gram negatif

\section{PEMBAHASAN}

Jumlah pasien yang terdata dalam penelitian ini sebanyak 103 pasien diabetes melitus, 14 pasien diantaranya sedang menggunakan obat antibiotik sehingga harus dieksklusikan dari penelitian ini agar data yang didapat tidak bias. Obat antibiotik yang masuk kedalam tubuh akan bekerja secara sistemik membunuh dan menghamat pertumbuhan bakteri, sehingga jika tetap dilakukan pemeriksaan bakteriuria hasil yang akan didapatkan tidak representative karena jumlahnya berkurang dan dikarenakan antibiotik merupakan salah satu terapi dalam infeksi saluran kemih.

\section{Sebaran Usia Pasien Diabetes Melitus}

Usia penderita diabetes melitus tipe 2 yang terdata dalam penelitian ini bervariasi dengan rata rata usia 58 tahun, usia termuda 18 tahun dan usia tertua 74 tahun. Hal ini menunjukkan bahwa diabetes melitus tipe 2 dapat terjadi pada usia muda sekalipun. Pada wawancara yang dilakukan peneliti, pasien termuda ini memiliki resiko riwayat keturunan DM dan pola makan yang tidak sehat.

Usia pasien tertua dalam penelitian ini adalah 74 tahun. Usia 74 tahun termasuk kedalam kategori lanjut usia menurut WHO. Pada lanjut usia terjadi degenerasi pada sistem tubuh, termasuklah sistem perkemihan yang dapat meningkatkan resiko terjadi infeksi saluran kemih pada diabetes melitus. ${ }^{12}$

\section{Karakterisitik Pasien Diabetes Melitus}

Karakteristik 89 pasien dalam penelitian ini didapatkan sebagian besar adalah perempuan $(57,30 \%)$, dengan usia lebih dari sama dengan 60 tahun sebesar 49,44\%. Dilihat dari lamanya menderita 
diabetes melitus, sebesar $70,79 \%$ pasien menderita kurang dari 10 tahun, dan sebesar $67,42 \%$ pasien timbul gejala infeksi saluran kemih.

Berdasarkan hasil penelitian, karakteristik subjek penelitian ini sesuai dengan peneliti-peneliti sebelumnya yang mendapatkan hasil sebagian besar penderita diabetes melitus adalah wanita. $^{19-21}$ Hasil penelitian lain didapatkan hasil, sebagian besar pasien menderita kurang dari 10 tahun. Namun pada variable gejala ISK sebagian besar memiliki gejala ISK atau simptomatik berbeda dengan hasil penelitian sebelumnya. $^{22}$

\section{Hasil Pemeriksaan Kultur Urin}

Dari hasil pemeriksaan kultur urin, didapatkan hasil negatif infeksi saluran kemih untuk seluruh sampel urin pasien diabetes melitus. Hasil pemeriksaan yang didapatkan peneliti berbeda dengan hasil penelitian-penelitian sebelumnya. Monica mendapatkan hasil $26,7 \%$ pasien diabetes melitus di rumah sakit bandung positif infeksi saluran kemih, ${ }^{6}$ penelitian lain di rumah sakit Bali oleh Ariwijaya mendapatkan hasil $36 \%$ pasien diabetes melitus positif infeksi saluran kemih, ${ }^{5}$ penelitian lain di rumah sakit di Malaysia oleh Shah dkk mendapatkan hasil prevalensi $40,2 \%,{ }^{26}$ dan penelitian di Nigeria oleh Mgbakogu mendapatkan hasil prevalensi sebesar $26 \%{ }^{23}$

Secara teori diabetes melitus akan melemahkan dari system imun dengan menurunkan konsentrasi interleukin-8, interleukin-6, dan leukosit. Diabetes melitus juga menurunkan kemampuan kontrol metabolik dan gangguan pengosongan bladder yang disebabkan neuropathy otonom meningkatkan resiko terjadi infeksi saluran kemih. ${ }^{23,26}$ Namun pada penelitian ini terdapat beberpa factor yang mempengaruhi hasil pemeriksaan yaitu, kadar glukosa darah, frekuensi, dan penggunaan antibiotik.

Pada penelitian Soelaeman ditemukan adanya hubungan buruknya pengendalian gula darah dan infeksi 
saluran kemih pada pasien diabetes melitus, ${ }^{27}$ dan Shah dkk mendapatkan 89,3\% infeksi saluran kemih terjadi pada pasien dengan kontrol gula darah yang buruk. ${ }^{26}$ Pada suatu penelitian didapatkan pasien diabetes melitus dengan nilai HbA1C lebih dari 8 memiliki resiko tinggi terjadi infeksi saluran kemih. ${ }^{28}$ Pada pemelitian ini tidak terdapat data kadar gula darah dan data nilai $\mathrm{HbA1C}$ pasien sehingga menjadi keterbatasan peneliti untuk menganalisis hasil kultur urin negatif pada pasien diabetes melitus yang dapat disebabkan baiknya kontrol gula darah saat pengambilan sampel.

Penelitian ini mendapatkan $41,57 \%$ dari seluruh sampel memiliki gejala frekuensi, frekuensi adalah gejala seringnya pasien untuk berkemih. Dan pada saat pengambilan sampel beberapa sampel mengatakan baru saja berkemih, sehingga urin yang keluar tidak banyak. Seringnya pasien untuk berkemih membuat banyak cairan yang keluar dari bladder dan membawa bakteri sehingga bakteri didalam bladder berkurang. ${ }^{29}$

Penelitian ini menggunakan metode wawancara dalam menyaring sampel yang menggunakan antibiotik dan tidak menggunakan antibiotik. Metode ini bergantung kepada kejujuran dan pengetahuan pasien tentang obat antibiotik. Penggunaan antibiotik termasuk kedalam kriteria ekslusi karena obat antibiotik yang masuk kedalam tubuh akan bekerja secara sistemik membunuh dan menghamat pertumbuhan bakteri, sehingga jika tetap dilakukan pemeriksaan bakteriuria hasil yang akan didapatkan hasil negatif palsu dikarenakan antibiotik merupakan salah satu terapi dalam infeksi saluran kemih. ${ }^{2}$

\section{Sebaran Gejala pada Pasien Diabetes}

\section{Melitus}

Pada penelitian ini gejala yang sering muncul secara berurutan yaitu Frekuensi (41,57\%), Nyeri panggul $(30,34 \%), \quad$ Urgensi $\quad(21,35 \%), \quad$ Nyeri suprapubic $(15,73 \%)$, Disuria $(6,74 \%)$, dan 
Demam (6,74\%). Gejala-gejala diatas adalah gejala infeksi saluran kemih yang dapat dijadikan dasar untuk mencurigai adanya infeksi saluran kemih pada pasien diabetes melitus. Pada pasien diabetes melitus cenderung untuk memiliki gejala infeksi saluran kemih yang berat. Meskipun beberapa pasien dengan neuropati diabetic dapat memiliki gejala yang berubah. ${ }^{24}$

\section{Sebaran jenis Gram bakteri pada pasien}

\section{diabetes melitus}

Pada pemeriksaan langsung dengan mikroskop didapatkan sebagian besar adalah bakteri basil gram negatif. Tingginya jenis bakteri basil Gram negatif dipengaruhi faktor-faktor yaitu ISK berulang, jenis kelamin wanita, diabetes melitus, penyakit prostat dan berhubungn dengan penggunaan obat kuinolon, aminopenicillin, penisilin, sefalosporin, dan antibiotic betalaktam. ${ }^{24}$ Selain itu flora normal yang terdapat pada anterior uretra juga mempengaruhi banyaknya jenis bakteri gram negatif. Flora normal terdiri dari Staphylococus epidermidis, Enterococcus faecalis, dan beberapa alpha-hemolytic streptococcus. Sedangkan beberapa bakteri enterik (E. coli, Proteus) dan corynebacteriae yang dapat mengkontaminasi dari kulit, vulva atau rektum yang flora normal yang paling banyak adalah bakteri coliform. ${ }^{25}$

\section{KESIMPULAN}

1. Prevalensi Infeksi saluran kemih pada pasien diabetes melitus sebesar $0 \%$.

2. Sebaran usia pasien diabetes melitus di RSUD Sultan Syarif Mohamad Alkadrie Pontianak adalah usia tertua 74 tahun dan usia termuda 18 tahun.

3. Karakteristik pasien diabetes melitus di RSUD Sultan Syarif Mohamad Alkadrie Pontianak terdiri $57,30 \%$ adalah perempuan, usia pasien lebih dari 60 tahun sebesar 49,44\%, lama menderita kurang dari 10 tahun 70,79\%, lama 
menderita 11 sampai 20 tahun

sebesar $22,47 \%$, dan lebih dari 20

tahun $6,74 \%$, dan sebesar $67,42 \%$

pasien mengatakan memiliki gejala

infeksi saluran kemih .

4. Sebaran gejala yang dirasakan

pasien diabetes melitus di RSUD

Sultan Syarif Mohamad Alkadrie

Pontianak adalah Frekuensi, Nyeri

Suprapubik, Nyeri Pinggang,

Urgensi, Disuria, dan Demam.

\section{DAFTAR PUSTAKA}

1. Kementrian Kesehatan RI. Riset Kesehatan Dasar. Jakarta: Meteri Kesehatan RI; 2013.

2. Sudoyo AW, Setiyohadi B, Alwi I, Simadibrata M, Setiati S. Buku Ajar Ilmu Penyakit Dalam. Jakarta: Fakultas Kedokteran Universitas Indonesia. 2014.

3. Soelistijo SA. Konsensus Pengelolaan Dan Pencegahan Diabetes Melitus Tipe 2 Di Indonesia 2015. PB. PERKENI; 2015.

4. Fünfstüc R. Urinary tractinfection inpatients withdiabetes mellitus. Clinical Nephrology. 2012;77.

5. Ariwijaya M, Suwitra K. Prevalensi, Karakteristik dan Faktor-Faktor yang Terkait dengan Infeksi Saluran Kemih pada Penderita Diabetes Melitus yang Rawat Inap. J Penyakit Dalam. 2007.

6. Saptiningsih M. Determinan Infeksi Saluran Kemih Pasien Diabetes Melitus Perempuan.

7. Fowler MJ. Microvascular and Macrovascular Complications of Diabetes. Diabetes Foundation; 2008.

8. Brooks GF, Butel JS, Morse SA. Mikrobiologi Kedokteran Jawetz, Melnick, \& Adelberg. 23rd ed. Jakarta: EGC; 2007.

9. WHO. Definition, Diagnosis and Classification of Diabetes Mellitus and Its Complications. geneva: WHO; 1999.

10. American Diabetes Association. Diabetes Care. Vol 38. care.diabetesjournals.org; 2015.
11. Waluyo I. Buku Petunjuk Praktikum Mikrobiologi Umum. malang: UMM; 2010.

12. Rowe TA, Juthani-Mehta M. Urinary tract infection in older adults. Future Medicine LTD. 2013.

13. Lestari DP. Hubungan Antara Kadar Glycosylated Hemoglobin (Hba1c) Dan Angka Kejadian Sindrom Dispepsia Pada Penderita Diabetes Melitus Tipe 2. Untan. 2015.

14. Putra oirul A. Gambaran Temuan Leukosituria Pada Pasien Diabetes Mellitus di Rumah Sakkit Umum Kota Tangerang Selatan Periode Januari-Juni Tahun 2013. UIN. 2013.

15. Mgbakogu RA, Eledo BO. Studies on Urinary Tract Infection among Diabetics in Some Eastern States of Nigeria. IISTE. 2015;34.

16. Nitzan Orna dkk. Urinary tract infections in patients with type 2 diabetes mellitus: review of prevalence, diagnosis, and management. Dovepress. 2015.

17. $\mathrm{Fu}$ alex $\mathrm{Z}$ dkk. Risk characterization for urinary tract infections in subjects with newly diagnosed type 2 diabetes. Elsevier. 2014.

18. Chen SL, Jackson SL, Boyko EJ. Diabetes Mellitus and Urinary Tract Infection: Epidemiology, Pathogenesis and Proposed Studies in Animal Models. American Urological Association. 2009.

19. CDC. Urinary Tract Infection. $C D C$. https://www.cdc.gov/antibioticuse/community/for-patients/commonillnesses/uti.html.

20. Boyko EJ dkk. Risk of urinary tract infection and symptomatic bacteriuria among diabetic and nondiabetic postmenopausal women. Pubmed. 2005.

21. Geerlings SE, Stolk RP, Camps MJ, et al. Risk factors for symptomatic urinary tract infection in women with diabetes. Diabetes care. 2000;23(12):1737-1741.

22. Meier S, Weber R, Zbinden R, Ruef C, Hasse B. Extended-spectrum $\beta$-lactamase-producing Gram-negative pathogens in communityacquired urinary tract infections: an increasing challenge for antimicrobial therapy. Infection. 2011;39(4):333-340.

23. Todar K. The Normal Bacterial Flora of Humans. www.textbookofbacteriology.net. 